medRxiv preprint doi: https://doi.org/10.1101/2021.12.06.21267361; this version posted December 7, 2021. The copyright holder for this preprint (which was not certified by peer review) is the author/funder, who has granted medRxiv a license to display the preprint in perpetuity.

All rights reserved. No reuse allowed without permission.

\title{
Global Assessment of IRF8 as a Novel Cancer Biomarker
}

Daniel C. McQuaid BS ${ }^{1}$; Gauri Panse MD'; Wei-Lien Wang MD²;

Samuel G. Katz, MD, PhD ${ }^{1 *}$; Mina L. Xu, MD ${ }^{1 *}$

1 Department of Pathology, Yale New-Haven Hospital, . Yale School of Medicine, New Haven, CT

2 Department of Pathology and Translational Molecular Pathology, University of Texas MD Anderson Cancer Center, Houston, TX

* These authors contributed equally to this work

13 Conflict of interest: The authors have no conflicts of interest to disclose.

14 Running Title: IRF8 IHC detects hematopoietic tumors

15 Keywords: Myeloid sarcoma, blastic plasmacytoid dendritic neoplasms, IRF8, cancer tissue 16 microarrays

Corresponding authors:

Samuel G. Katz

20 Email: samuel.katz@yale.edu

21 Phone: 203-785-2757

22 Fax: 203-785-3583

23310 Cedar Street, LH315B

24 New Haven, CT 06510

25 Mina L. Xu

26 Email: mina.xu@yale.edu

27 Phone: 203-737-6135

28 Fax: 203-785-6135

29310 Cedar Street, BML116

30 New Haven, CT 06510 
medRxiv preprint doi: https://doi.org/10.1101/2021.12.06.21267361; this version posted December 7, 2021. The copyright holder for this preprint (which was not certified by peer review) is the author/funder, who has granted medRxiv a license to display the preprint in perpetuity.

All rights reserved. No reuse allowed without permission.

\section{Abstract}

32 Interferon regulatory factor 8 (IRF8) is a member of the IRF family that is specific to the

33 hematopoietic cell and is involved in regulating the development of human monocytic and

34 dendritic-lineage cells, as well as B cells. Since its utility as a sensitive and specific monoblast

35 marker in the context of acute monocytic leukemias has been recently demonstrated, we

36 hypothesized that it may also be useful as a novel immunohistochemical marker in myeloid

37 sarcomas and blastic plasmacytoid dendritic cell neoplasms (BPDCN) with respect to their

38 differential diagnoses. In this retrospective study, we analyzed the IHC expression pattern of

39 IRF8 in 385 patient samples across 30 types of cancers, referenced to their mRNA expression

40 data available through TCGA. In addition, we assessed IRF8 in 35 myeloid sarcomas, and 13

41 BPDCNs. Twenty-four of 35 cases of myeloid sarcomas (68.5\%) showed positivity for IRF8, with

42 six cases (17.1\%) demonstrating IRF8 expression in the absence of CD34 and MPO. All 13 of 13

BPDCNs (100\%) showed strong uniform expression of IRF8 and was occasionally more definitive

44 than CD123. IRF8 was negative in all desmoplastic small round cell tumors, Ewing sarcomas,

45 synovial sarcomas, and undifferentiated pleomorphic sarcomas, as well as all epithelial

46 malignancies tested except for 2 triple negative breast cancers that showed subset weak

47 staining. In conclusion, IRF8 is a novel marker helpful in identifying extranodal hematopoietic

48 tumors that can otherwise be difficult to diagnose given the broad differential diagnoses and

49 frequent loss of more common lineage-defining markers.

50

51 
medRxiv preprint doi: https://doi.org/10.1101/2021.12.06.21267361; this version posted December 7, 2021. The copyright holder for this preprint (which was not certified by peer review) is the author/funder, who has granted medRxiv a license to display the preprint in perpetuity.

All rights reserved. No reuse allowed without permission.

\section{0: Introduction}

54 Interferon regulatory factor 8 (IRF8) is a hematopoietic-specific member of the IRF family that is essential in the commitment of myeloid progenitors to monocyte, macrophage, and dendritic cell lineages $(1,2)$. IRF8 expression is significantly elevated in monocyte-dendritic cell

57 progenitors in mice and conversely, $\operatorname{Irf} 8^{-/-}$mice lack bone marrow resident macrophages, dendritic cells, and plasmacytoid dendritic cells in lymphatic tissue (3-5). The role of IRF8 in the generation of monocyte and dendritic cell progenitors is conserved in humans, as mutations that impair IRF8 transcriptional activity are associated with immunodeficiency via decreased

61 monocyte and dendritic cell populations (6). Past work has shown that IRF8 is upregulated in

62 subsets of acute myeloid leukemia (AML) and correlates with poor prognosis in AML patients

63 (7). Moreover, we recently demonstrated that IRF8 immunohistochemistry stains monoblasts in

64 cases of acute monocytic leukemia and advanced chronic myelomonocytic leukemia, but is negative in mature monocytes and granulocytes (8). Given this observation, IRF8 may hold promise as a biomarker for additional malignancies derived from early monocyte and dendritic cell precursors. granulocyte populations that manifests as an extramedullary soft tissue mass (9). It is defined

71 by the World Health Organization as a tumor of myeloid blasts that occurs at an anatomic

72 location beyond the bone marrow (10). Myeloid sarcoma typically develops secondary to AML,

73 although rare cases of isolated disease without bone marrow involvement or history of myeloid 74 malignancy have been described (11). These tumors most commonly arise at the lymph nodes, 
medRxiv preprint doi: https://doi.org/10.1101/2021.12.06.21267361; this version posted December 7, 2021. The copyright holder for this preprint (which was not certified by peer review) is the author/funder, who has granted medRxiv a license to display the preprint in perpetuity.

All rights reserved. No reuse allowed without permission.

75 skin, soft tissues, and bone, and must cause effacement of local tissue in order to render a

76 myeloid sarcoma diagnosis (10). Due to the disparate sites of disease involvement, clinical

77 presentation is varied and pathology evaluation is critical for diagnosis. However, myeloid

78 sarcoma is notoriously difficult to diagnose, with an estimated misdiagnosis rate of $25-47 \%$ (12-

79 14). This diagnostic inaccuracy is a product of disease rarity, particularly in the absence of a

80 known myeloid disorder, as well as a dearth of markers for staining (15). Histologically, the

81 tumor demonstrates myeloid cell infiltration with myeloblasts or monoblasts (16). Of note,

82 lesions with granulocytic differentiation have features such as eosinophilic metamyelocytes

83 that aid in a myeloid sarcoma diagnosis, while tumors of monocytic origin lack these

84 characteristics and are typically more difficult to diagnose (12). Consequently, additional

85 biomarkers are needed to ameliorate the diagnostic challenges of this extramedullary

86 malignancy.

88 Blastic plasmacytoid dendritic cell neoplasm (BPDCN) is an aggressive hematopoietic disorder of

89 plasmacytoid dendritic cells (17). BPDCN is a rare cancer, estimated to account for less than $1 \%$

90 of all hematologic malignancies, or roughly 700 cases annually in the United States $(18,19)$. In

$9190 \%$ of patients, BPDCN presents with skin manifestations and is later accompanied by

92 involvement of bone marrow, peripheral blood, and lymph nodes $(20,21)$. Progression to

93 systemic disease is rapid, and median survival is estimated to be between 12 and 14 months

94 (22). Diagnosis of BPDCN relies on clinical presentation, histological evaluation of the lesion,

95 and immunophenotyping (23). Due to cutaneous involvement that presents with blast cells in

96 the dermis, suspicion is often high for soft tissue tumors, T-cell leukemias/lymphomas, and NK- 
medRxiv preprint doi: https://doi.org/10.1101/2021.12.06.21267361; this version posted December 7, 2021. The copyright holder for this preprint (which was not certified by peer review) is the author/funder, who has granted medRxiv a license to display the preprint in perpetuity.

All rights reserved. No reuse allowed without permission.

97 cell leukemias/lymphomas (22). It can be difficult to differentiate these malignancies from

98 BPDCN, and immunophenotyping is critical to validate the observed skin lesions are comprised

99 of plasmacytoid dendritic cells rather than myeloid or lymphoid blasts (24). Additionally,

100 expression of antigens expressed by other cell lineages, such as CD56 on NK/T-cell

101 leukemia/lymphomas, and CD4 and CD123 on AMLs can make it difficult to render a definitive

102 diagnosis (25). Thus, additional immunohistochemical markers in the diagnostic panel of BPDCN

103 can help differentiate this malignancy from others with similar morphologic characteristics and

104 clinical presentations.

106 We hypothesized that IRF8 may serve as a useful biomarker for myeloid sarcoma and BPDCN

107 due to their prominent monoblastic and dendritic cell origin, respectively. Herein, we

108 demonstrate that IRF8 is able to stain neoplastic cells of both myeloid sarcoma and BPDCN,

109 even in cases lacking traditional markers for these malignancies. Importantly, IRF8 expression is

110 absent in a panel of soft-tissue cancers that could potentially mimic myeloid sarcoma and

111 BPDCN, as well as solid tumors. Our work demonstrates the utility for IRF8 in the identification

112 of these rare hematologic malignancies that are in need of additional markers to aid in

113 diagnosis.

\section{2.0: Methods}

\section{2.1: Human Tumor Samples and TMA Creation}

11735 cases of myeloid sarcoma and 13 cases of BPDCN were obtained following approval by the

118 Yale institutional review board. All cases were diagnosed by board-certified pathologists at the 
medRxiv preprint doi: https://doi.org/10.1101/2021.12.06.21267361; this version posted December 7, 2021. The copyright holder for this preprint (which was not certified by peer review) is the author/funder, who has granted medRxiv a license to display the preprint in perpetuity.

All rights reserved. No reuse allowed without permission.

119 Yale School of Medicine according to their WHO criteria and validated by a second reviewer at

120 outside institutions. Both a pan-cancer tissue microarray of 150 cases spanning 25 tumor

121 subtypes and 27 tissue-matched normal samples as well as a triple-negative breast cancer-

122 specific TMA of 97 cases were made in the Department of Pathology at the Yale School of

123 Medicine. All cases were previously diagnosed at Yale and utility of these biopsies in this study

124 was approved by the Yale institutional review board. In addition, we used specimens from

125 select sections of various previously published sarcoma-specific TMAs, including desmoplastic

126 small round cell tumor $(n=30)$, Ewing sarcoma $(n=24)$, synovial sarcoma $(n=45)$, and

127 undifferentiated pleomorphic sarcoma $(n=12)$.

\section{2: IHC Staining and Scoring}

130 Immunohistochemistry (IHC) of all aforementioned samples and TMAs was performed using a

131 rabbit monoclonal IRF8 antibody (Anti-IRF8 ab207418 from Abcam, 1:900 dilution) as previously

132 described (8). We additionally stained myeloid sarcoma samples with both myeloperoxidase

133 (MPO rabbit polyclonal concentrate from Dako, 1:10 000 dilution) and CD34 (QBEND from

134 Ventana, Neat), and BPDCN samples with CD123 (9F5 from BD Biosciences, 1:50 dilution). Cases

135 that were double stained with IRF8 and lysozyme utilized the double-staining protocol on Bond

136 with lysozyme (polyclonal from Agilent, Neat). To perform staining, formalin-fixed, paraffin-

137 embedded tumor tissue sections were deparaffinized and rehydrated prior to antigen retrieval

138 and primary antibody incubation. Afterward, specimens were incubated with diaminobenzidine

139 (DAB) chromagen for primary antibody detection and counterstained with hematoxylin. All

140 stained samples were evaluated for both percentage of immunoreactive cells and staining 
medRxiv preprint doi: https://doi.org/10.1101/2021.12.06.21267361; this version posted December 7, 2021. The copyright holder for this preprint (which was not certified by peer review) is the author/funder, who has granted medRxiv a license to display the preprint in perpetuity.

All rights reserved. No reuse allowed without permission.

141 intensity (0, negative; $1+$, weak; $2+$, moderate; $3+$, strong) (26). When possible for both TMAs

142 and whole tissue sections, at least 3 non-adjacent fields containing tumor cells were evaluated

143 for IRF8 staining. Only IRF8 nuclear staining of neoplastic cells was considered positive, as

144 several samples demonstrated cytoplasmic staining of cancerous cells or nuclear staining of

145 infiltrating lymphocytes. Nuclear reactivity at any intensity was denoted as positive for IRF8 and

146 given as percentage of overall tumor cells in a sample. Percentage of positive cells within tumor

147 was also scored for CD34 and MPO in all myeloid sarcoma cases.

\section{3: TCGA Database Analysis}

150 Expression levels of IRF8 across different cancer types and their matched normal tissue were

151 analyzed using Gene Expression Profiling Interactive Analysis (GEPIA), which utilizes global RNA-

152 Seq data from The Cancer Genome Atlas (TCGA) and Genotype-Tissue Expression (GTEx)

153 databases. While TCGA contains expression data from 33 types of cancer, we collated this

154 dataset to only analyze subtypes that were represented in our pan-cancer and sarcoma TMAs.

155 We then determined the log2 fold change of IRF8 expression between cancerous and normal

156 tissue, utilizing a fold-change threshold of 1 and a p-value cutoff of 0.01 (as determined by a

157 one-way ANOVA) to identify significantly different IRF8 transcript abundance between these

158 two groups.

\section{$160 \quad$ 3.0: Results}

161 3.1: IRF8 abundance is elevated in monocyte-derived myeloid sarcoma

162 In order to investigate IRF8 expression in tumors of monocytic origin, we evaluated its abundance 
medRxiv preprint doi: https://doi.org/10.1101/2021.12.06.21267361; this version posted December 7, 2021. The copyright holder for this preprint (which was not certified by peer review) is the author/funder, who has granted medRxiv a license to display the preprint in perpetuity.

All rights reserved. No reuse allowed without permission.

163 in myeloid sarcoma, an extramedullary malignancy of neoplastic immature monocytes and/or

164 granulocytes (9). We performed immunohistochemical staining of 35 myeloid sarcoma patient

165 samples and concomitantly stained for CD34, a hematopoietic stem cell marker, and

166 myeloperoxidase (MPO), a myeloid marker. IRF8 was detectable in 24 of 35 (68.5\%) of these

167 cases, and CD34 was often undetectable in cases with the greatest degree of IRF8 positivity

168 (Figure 1). Importantly, there were six cases for which IRF8 positivity was observed in the absence

169 of CD34 or MPO expression, suggesting that IRF8 is able to identify myeloid sarcomas of primarily

170 monocytic origin (Figure 2). In order to confirm monocytic origin of these blasts, double staining

171 with lysozyme was performed on select MPO-negative specimens with sufficient remaining

172 tissue. These showed blasts that were IRF8+ lysozyme+ as well as background scattered mature

173 monocytes that were IRF8- lysozyme+ (Figure 3).

3.2: IRF8 is expressed in blastic plasmacytoid dendritic cell neoplasm

176 After observing IRF8 upregulation in myeloid sarcoma, we next investigated IRF8 abundance in

177 blastic plasmacytoid dendritic cell neoplasm (BPDCN), a rare hematopoietic malignancy arising

178 from immature plasmacytoid dendritic cells (17). Staining of 13 BPDCN cases demonstrated

179 uniform IRF8 expression, with 13/13 (100\%) samples showing positive IRF8 staining by

180 immunohistochemistry. Importantly, there were multiple cases that stained negative for CD123,

181 a marker commonly used in the diagnosis of BPDCN, but positive for IRF8 (Figure 4). This finding

182 suggests that IRF8 holds promise as a marker for multiple difficult-to-diagnose hematologic

183 malignancies of monocytic or dendritic cell origin. 
medRxiv preprint doi: https://doi.org/10.1101/2021.12.06.21267361; this version posted December 7, 2021. The copyright holder for this preprint (which was not certified by peer review) is the author/funder, who has granted medRxiv a license to display the preprint in perpetuity.

All rights reserved. No reuse allowed without permission.

185

186

187

188

189

190

191

192

193

194

195

196

197

198

199

200

201

202

203

204

205

206

\section{3: Assessment of IRF8 expression across different cancer types}

We next sought to evaluate IRF8 expression across additional tumor types and normal tissues in order to validate that presence of IRF8 is specific to hematopoietic malignancies. Consequently, we performed IRF8 staining of a pan-cancer TMA comprising 177 patient samples of both normal and cancerous tissue across 11 tissue types and 25 cancer subtypes. IRF8 expression was negative in all normal tissue samples and all but one tumor sample, which was a diffuse large B-cell lymphoma of the testis (Table 1, Figure 5). We also sought to further evaluate IRF8 expression in breast cancer, as our small cohort of breast cancers in the initial pan-cancer TMA were devoid of triple-negative breast cancers (TNBCs). We additionally assessed IRF8 expression on a TMA of 97 TNBCs and observed that $2(2.1 \%)$ of these tumors were IRF8-positive. The staining pattern for these cases was weak and showed subset reactivity (Figure 5). In many samples, we observed IRF8 staining of background lymphocytes that spared large, neoplastic cells.

We next analyzed publicly available expression data from The Cancer Genome Atlas (TCGA) to further assess IRF8 expression between normal and cancerous tissues for malignancies included in the TMA. In line with previous reports, IRF8 was significantly upregulated in acute myeloid leukemia and diffuse large B-cell lymphoma samples relative to normal tissue (7). However, IRF8 mRNA expression was also increased in colon adenocarcinoma, stomach adenocarcinoma, and testicular germ cell tumors (Figure 6). While these tumors were represented in our pan-cancer TMA, we did not observe a similar upregulation of IRF8 protein in the neoplastic cells, but rather in infiltrating lymphocytes (Table 1). 
medRxiv preprint doi: https://doi.org/10.1101/2021.12.06.21267361; this version posted December 7, 2021. The copyright holder for this preprint (which was not certified by peer review) is the author/funder, who has granted medRxiv a license to display the preprint in perpetuity.

All rights reserved. No reuse allowed without permission.

207 We next performed IRF8 staining on sarcoma TMAs of subtypes that may be considered in the

208 differential diagnosis of myeloid sarcoma or BPDCN. IRF8 expression was not observed in any of

209 the 111 soft-tissue tumors belonging to 4 subtypes of sarcomas in these TMAs, which included

210 desmoplastic small round cell tumor, Ewing sarcoma, synovial sarcoma, and undifferentiated

211 pleomorphic sarcoma (Table 2). These results indicate that IRF8 expression is specifically

212 upregulated in monocyte-derived soft-tissue tumors and can be utilized to identify myeloid

213 sarcomas that lack CD34 or MPO expression. Taken together, these findings suggest that

214 increased abundance of IRF8 has the potential to distinguish malignant cells across several cancer

215 types and is most significantly associated with hematologic malignancies.

217 4.0: Discussion

218 Malignancies derived from monoblasts are often difficult to diagnose, owing to their occasional

219 morphologic overlap with other malignancies as well as a dearth of reliable

220 immunohistochemical stains for these early hematopoietic progenitors (27). We recently

221 identified IRF8 as a sensitive and specific monoblast marker in cases of acute monocytic

222 leukemia (AMoLs) by demonstrating its strong correlation with aspirate blast count in AMoLs

223 (8). IRF8 is a transcription factor that upregulates genes critical for the differentiation of

224 monocytes, dendritic cells, and macrophages (2). Prior work has demonstrated that IRF8

225 expression peaks in monocyte and dendritic cell precursors, and thereafter remains high in

226 mature dendritic cells but rapidly decreases in mature monocytes, suggesting it will potently

227 stain immature monocytic/dendritic cell populations $(3,28)$. Herein, we have demonstrated 
medRxiv preprint doi: https://doi.org/10.1101/2021.12.06.21267361; this version posted December 7, 2021. The copyright holder for this preprint (which was not certified by peer review) is the author/funder, who has granted medRxiv a license to display the preprint in perpetuity.

All rights reserved. No reuse allowed without permission.

228 that IRF8 is expressed in multiple hematologic malignancies of monoblastic/dendritic cell origin

229 and holds promise as a biomarker for these difficult-to-diagnose neoplasms.

231 Given our recent work demonstrating IRF8 as a reliable monoblast marker, we sought to

232 evaluate the utility of IRF8 in staining monocyte-derived hematopoietic cancers for which

233 clinical diagnosis is challenging and helpful tissue markers are lacking. We first stained for IRF8

234 in samples of myeloid sarcoma, an extramedullary tumor of mixed immature granulocyte and

235 monocyte origin (15). Myeloid sarcoma can rarely occur as an isolated disease but is most

236 commonly observed as a manifestation of acute myeloid leukemia, being reported in roughly

$237 \quad 2.5-9.1 \%$ of AML patients (11). It is often difficult for pathologists to diagnose, particularly in the

238 absence of a previous AML diagnosis; prior studies have estimated that between $25-47 \%$ of

239 myeloid sarcoma cases are misdiagnosed, largely due to inadequate immunophenotyping of

240 the lesion (12-14). Consequently, we posited that IRF8 could be utilized to stain myeloid

241 sarcoma cases with prominent monoblast populations. IRF8 was able to stain a significant

242 proportion of myeloid sarcoma cases, including those negative for CD34 and MPO; these cases

243 that had previous/concurrent marrows did indeed demonstrate monocytic differentiation by

244 aspirate morphology with or without flow immunophenotypic support. Additionally, IRF8 did

245 not stain any other soft-tissue tumors on sarcoma TMAs representing some of the differential

246 diagnoses of myeloid sarcoma, including Ewing sarcoma, undifferentiated pleomorphic

247 sarcoma, desmoplastic small round cell tumor and synovial sarcoma (29). Thus, IRF8 can be

248 utilized as a biomarker for myeloid sarcoma and has the potential to improve diagnostic 
medRxiv preprint doi: https://doi.org/10.1101/2021.12.06.21267361; this version posted December 7, 2021. The copyright holder for this preprint (which was not certified by peer review) is the author/funder, who has granted medRxiv a license to display the preprint in perpetuity.

All rights reserved. No reuse allowed without permission.

249 accuracy of this less common hematologic malignancy, particularly for cases which are primarily

250 of monocytic origin.

252 We next evaluated the utility of IRF8 in staining malignant cells in blastic plasmacytoid dendritic

253 cell neoplasm (BPDCN). BPDCN is an aggressive, rare tumor derived from precursors of

254 plasmacytoid dendritic cells that often presents asymptomatically or with multiple bruise-like

255 cutaneous lesions before progressing to involve extracutaneous sites (20). In roughly $66 \%$ of

256 patients, BPDCN presents as stage IV disease at time of diagnosis, and median survival is

257 estimated to be between 12 and 14 months (22). BPDCN diagnosis is made on the basis of

258 clinical features, morphological findings, and immunophenotype. Diagnosis is challenging, and

259 BPDCN is often difficult to distinguish from soft-tissue tumors, AML, and T-cell

260 leukemias/lymphomas. This is due to both an overlap in immunophenotyping as well as the

261 common lymphoid-like morphology of BPDCN blasts that leads to a false suspicion of

262 lymphoma (30). Given the dendritic cell lineage of BPDCN blasts and the diagnostic difficulties

263 associated with the disease, we hypothesized that IRF8 could be a useful tool in staining

264 neoplastic BPDCN cells. All 13 samples we obtained of this highly rare tumor were strongly

265 positive for IRF8 staining. Additionally, several of these IRF8-positive cases were negative for

266 CD123, a marker commonly used for BPDCN, suggesting that IRF8 may be a useful marker to

267 add to the diagnostic panel for this aggressive hematopoietic malignancy (31).

269 Following the identification of positive IRF8 staining in myeloid sarcoma and BPDCN, we sought

270 to determine if its expression is specific to cancers of hematologic origin. We showed that IRF8 
medRxiv preprint doi: https://doi.org/10.1101/2021.12.06.21267361; this version posted December 7, 2021. The copyright holder for this preprint (which was not certified by peer review) is the author/funder, who has granted medRxiv a license to display the preprint in perpetuity.

All rights reserved. No reuse allowed without permission.

271 did not stain any solid tumors or normal tissue on a pan-cancer TMA comprising 25 cancer

272 subtypes. However, global expression data from The Cancer Genome Atlas (TCGA) suggested

273 that IRF8 is transcriptionally upregulated in several carcinomas relative to normal tissue,

274 particularly colon adenocarcinoma, stomach adenocarcinoma, and testicular germ cell tumors,

275 all of which were represented in our TMA. In contrast to this TCGA data, prior reports have

276 indicated that IRF8 expression is preferentially decreased in both colon and gastric cancer

277 samples relative to noncancerous tissue, through mechanisms such as increased promoter

278 methylation $(32,33)$. This discrepancy highlights the discordance that can be observed between

279 TCGA data and primary patient samples. Moreover, while breast cancers represented in the

280 pan-cancer TMA were uniformly IRF8-negative, we performed additional staining on a TMA

281 specific for triple-negative breast cancers (TNBCs) due to a recent study documenting increased

282 IRF8 expression in estrogen receptor-negative breast cancers (34). However, only rare cases

283 (2.1\%) of the TNBCs in this TMA stained weakly positive for IRF8. This observation is potentially

284 due to the fact that these investigators found IRF8 expression to be increased specifically in

285 early-stage ER-negative cancers, which may not have been as well represented on the TMA as

286 advanced disease. Importantly, and in line with recent work, IRF8 upregulation was most

287 significantly associated with AML and diffuse large b-cell lymphoma in the TCGA dataset,

288 further indicating that IRF8 likely has greatest utility as a marker of hematopoietic neoplasms

289 (7).

290

291 In this study, we demonstrate that IRF8 can be used to identify monocyte and dendritic cell-

292 derived malignancies that are prone to misdiagnosis due to a scarcity of specific markers. Our 
medRxiv preprint doi: https://doi.org/10.1101/2021.12.06.21267361; this version posted December 7, 2021. The copyright holder for this preprint (which was not certified by peer review) is the author/funder, who has granted medRxiv a license to display the preprint in perpetuity.

All rights reserved. No reuse allowed without permission.

293 study is limited by the relatively few cases of BPDCN. In addition, since B-cell lymphomas are

294 also positive for IRF8, the marker does not help to differentiate among hematopoietic tumors.

295 Further validation of these findings will be critical in order to integrate IRF8 staining into

296 pathologists' workflow for diagnosis of these diseases. Additionally, future studies should build

297 upon this work by determining if differential IRF8 expression correlates with poor prognosis or

298 response to therapy in the diseases it stains. While this will likely prove challenging due to the

299 rarity of both myeloid sarcoma and BPDCN, identifying additional prognostic markers for these

300 diseases is crucial, particularly given the lack of data regarding survival differences between

301 granulocyte-predominant and monocyte-predominant myeloid sarcoma (35). IRF8 thus may

302 hold promise not only as a marker for diagnosis but also as a prognostic indicator that guides

303 treatment intervention for these rare hematopoietic neoplasms.

305 Acknowledgements

306 We acknowledge Amos Brooks and Lori Charette from Yale Pathology Tissue Services for their

307 invaluable experience and aid with immunohistochemical studies as well as tissue procurement

308 and processing.

309

310 Conflict of Interest

311 The authors have disclosed that they have no significant relationships with, or financial interest

312 in any commercial companies pertaining to this article.

313

314 Ethics Approval and Consent to Participate 
medRxiv preprint doi: https://doi.org/10.1101/2021.12.06.21267361; this version posted December 7, 2021. The copyright holder for this preprint (which was not certified by peer review) is the author/funder, who has granted medRxiv a license to display the preprint in perpetuity.

All rights reserved. No reuse allowed without permission.

315 The study was performed in accordance with the Declaration of Helsinki. The study was

316 approved by an internal review board (local ethics committee HIC protocol \#2000023891).

317

318 Author Contributions

319 D.C.M., S.G.K., and M.L.X. contributed equally in conception and design. D.C.M., M.L.X, and G.P.

320 carried out data analysis. W.W. contributed additional cases. D.C.M. wrote the manuscript with

321 significant contributions from M.L.X. and S.G.K. All authors edited the manuscript.

322

323 Funding

324 The authors have no funding sources to declare.

325

326

Data Availability

327 The tissue sections analyzed during this study are available from the corresponding author

328 upon request. TCGA data analyzed during this study are publicly available using the GEPIA

329 online resource.

330

331

332

333

334

335

336 


\section{References}

338 1. Tamura T, Nagamura-Inoue T, Shmeltzer Z, Kuwata T, Ozato K. ICSBP directs bipotential

339 myeloid progenitor cells to differentiate into mature macrophages. Immunity. 2000;13(2):155-

34065.

341 2. Kurotaki D, Osato N, Nishiyama A, Yamamoto M, Ban T, Sato H, et al. Essential role of the

342 IRF8-KLF4 transcription factor cascade in murine monocyte differentiation. Blood.

$343 \quad 2013 ; 121(10): 1839-49$.

344 3. Kurotaki D, Yamamoto $M$, Nishiyama A, Uno K, Ban T, Ichino $M$, et al. IRF8 inhibits C/EBP $\alpha$

345 activity to restrain mononuclear phagocyte progenitors from differentiating into neutrophils.

$346 \quad$ Nat Commun. 2014;5:4978.

347 4. Tsujimura H, Tamura T, Ozato K. Cutting edge: IFN consensus sequence binding protein/IFN

348 regulatory factor 8 drives the development of type I IFN-producing plasmacytoid dendritic cells.

349 J Immunol. 2003;170(3):1131-5.

350 5. Yamamoto M, Kato T, Hotta C, Nishiyama A, Kurotaki D, Yoshinari M, et al. Shared and

351 distinct functions of the transcription factors IRF4 and IRF8 in myeloid cell development. PLoS

352 One. 2011;6(10):e25812.

353 6. Hambleton S, Salem S, Bustamante J, Bigley V, Boisson-Dupuis S, Azevedo J, et al. IRF8

354 mutations and human dendritic-cell immunodeficiency. N Engl J Med. 2011;365(2):127-38.

355 7. Liss F, Frech M, Wang Y, Giel G, Fischer S, Simon C, et al. IRF8 Is an AML-Specific Susceptibility

356 Factor That Regulates Signaling Pathways and Proliferation of AML Cells. Cancers (Basel).

$357 \quad 2021 ; 13(4)$. 

Leukemias. Am J Surg Pathol. 2021;45(10):1391-8.

9. Alexiev BA, Wang W, Ning Y, Chumsri S, Gojo I, Rodgers WH, et al. Myeloid sarcomas: a

361 histologic, immunohistochemical, and cytogenetic study. Diagn Pathol. 2007;2:42.

362 10. Vardiman JW, Thiele J, Arber DA, Brunning RD, Borowitz MJ, Porwit A, et al. The 2008

363 revision of the World Health Organization (WHO) classification of myeloid neoplasms and acute

364 leukemia: rationale and important changes. Blood. 2009;114(5):937-51.

365 11. Bakst RL, Tallman MS, Douer D, Yahalom J. How I treat extramedullary acute myeloid

366 leukemia. Blood. 2011;118(14):3785-93.

367 12. Almond LM, Charalampakis M, Ford SJ, Gourevitch D, Desai A. Myeloid Sarcoma:

368 Presentation, Diagnosis, and Treatment. Clin Lymphoma Myeloma Leuk. 2017;17(5):263-7.

369 13. Antic D, Elezovic I, Milic N, Suvajdzic N, Vidovic A, Perunicic M, et al. Is there a "gold"

370 standard treatment for patients with isolated myeloid sarcoma? Biomed Pharmacother.

$371 \quad 2013 ; 67(1): 72-7$.

372 14. Yamauchi K, Yasuda M. Comparison in treatments of nonleukemic granulocytic sarcoma:

373 report of two cases and a review of 72 cases in the literature. Cancer. 2002;94(6):1739-46.

374 15. Magdy M, Abdel Karim N, Eldessouki I, Gaber O, Rahouma M, Ghareeb M. Myeloid

375 Sarcoma. Oncol Res Treat. 2019;42(4):224-9.

376 16. Pileri SA, Ascani S, Cox MC, Campidelli C, Bacci F, Piccioli M, et al. Myeloid sarcoma: clinico377 pathologic, phenotypic and cytogenetic analysis of 92 adult patients. Leukemia. 2007;21(2):34037850. 

profiling of blastic plasmacytoid dendritic cell neoplasm reveals a unique pattern and suggests

381 selective sensitivity to NF-kB pathway inhibition. Leukemia. 2014;28(8):1606-16.

383 characteristics of CD4(+)/HLA DRhi dendritic cell malignancies. Haematologica. 2004;89(1):58-

69. plasmacytoid dendritic cell neoplasm with leukemic presentation: an Italian multicenter study. Haematologica. 2013;98(2):239-46.

20. Cota C, Vale E, Viana I, Requena L, Ferrara G, Anemona L, et al. Cutaneous manifestations of blastic plasmacytoid dendritic cell neoplasm-morphologic and phenotypic variability in a series

390 of 33 patients. Am J Surg Pathol. 2010;34(1):75-87.

391 21. Julia F, Petrella T, Beylot-Barry M, Bagot M, Lipsker D, Machet L, et al. Blastic plasmacytoid

392 dendritic cell neoplasm: clinical features in 90 patients. Br J Dermatol. 2013;169(3):579-86.

393 22. Shi Y, Wang E. Blastic plasmacytoid dendritic cell neoplasm: a clinicopathologic review. Arch

394 Pathol Lab Med. 2014;138(4):564-9.

395 23. Sullivan JM, Rizzieri DA. Treatment of blastic plasmacytoid dendritic cell neoplasm.

396 Hematology Am Soc Hematol Educ Program. 2016;2016(1):16-23.

397 24. Deotare U, Yee KW, Le LW, Porwit A, Tierens A, Musani R, et al. Blastic plasmacytoid 398 dendritic cell neoplasm with leukemic presentation: 10-Color flow cytometry diagnosis and 399 HyperCVAD therapy. Am J Hematol. 2016;91(3):283-6. 
medRxiv preprint doi: https://doi.org/10.1101/2021.12.06.21267361; this version posted December 7, 2021. The copyright holder for this preprint (which was not certified by peer review) is the author/funder, who has granted medRxiv a license to display the preprint in perpetuity.

All rights reserved. No reuse allowed without permission.

400 25. Garnache-Ottou F, Feuillard J, Ferrand C, Biichle S, Trimoreau F, Seilles E, et al. Extended

401 diagnostic criteria for plasmacytoid dendritic cell leukaemia. Br J Haematol. 2009;145(5):624-

40236.

403 26. Parris TZ, Aziz L, Kovács A, Hajizadeh S, Nemes S, Semaan M, et al. Clinical relevance of

404 breast cancer-related genes as potential biomarkers for oral squamous cell carcinoma. BMC

405 Cancer. 2014;14:324.

406 27. Goasguen JE, Bennett JM, Bain BJ, Vallespi T, Brunning R, Mufti GJ. Morphological

407 evaluation of monocytes and their precursors. Haematologica. 2009;94(7):994-7.

408 28. Sichien D, Scott CL, Martens L, Vanderkerken M, Van Gassen S, Plantinga M, et al. IRF8

409 Transcription Factor Controls Survival and Function of Terminally Differentiated Conventional

410 and Plasmacytoid Dendritic Cells, Respectively. Immunity. 2016;45(3):626-40.

411 29. Marwah N, Bhutani N, Budhwar A, Sen R. Isolated myeloid sarcoma of the temporal bone:

412 As the first clinical manifestation of acute myeloid leukemia in a patient of down's syndrome.

413 Int J Surg Case Rep. 2019;58:77-80.

414 30. Garnache-Ottou F, Vidal C, Biichlé S, Renosi F, Poret E, Pagadoy M, et al. How should we

415 diagnose and treat blastic plasmacytoid dendritic cell neoplasm patients? Blood Adv.

$416 \quad$ 2019;3(24):4238-51.

417 31. Laribi K, Denizon N, Besançon A, Farhi J, Lemaire P, Sandrini J, et al. Blastic Plasmacytoid

418 Dendritic Cell Neoplasm: From Origin of the Cell to Targeted Therapies. Biol Blood Marrow

419 Transplant. 2016;22(8):1357-67. 
medRxiv preprint doi: https://doi.org/10.1101/2021.12.06.21267361; this version posted December 7, 2021. The copyright holder for this preprint (which was not certified by peer review) is the author/funder, who has granted medRxiv a license to display the preprint in perpetuity.

All rights reserved. No reuse allowed without permission.

420 32. Ibrahim MLL, K. IRF8 deficiency in colonic epithelial cells promotes inflammation-mediated

421 colon tumorigenesis and myeloid-derived suppressor cell differentiation. J Immunol.

$422 \quad 2017 ; 198(66.20)$.

423 33. Yamashita M, Toyota M, Suzuki H, Nojima M, Yamamoto E, Kamimae S, et al. DNA

424 methylation of interferon regulatory factors in gastric cancer and noncancerous gastric

425 mucosae. Cancer Sci. 2010;101(7):1708-16.

426 34. Gatti G, Betts C, Rocha D, Nicola M, Grupe V, Ditada C, et al. High IRF8 expression correlates

427 with CD8 T cell infiltration and is a predictive biomarker of therapy response in ER-negative

428 breast cancer. Breast Cancer Res. 2021;23(1):40.

429 35. Avni B, Koren-Michowitz M. Myeloid sarcoma: current approach and therapeutic options.

430 Ther Adv Hematol. 2011;2(5):309-16.

431

432

433

434

435

436

437

438

439

440

441 
443 Figure 1: IRF8 expression in myeloid sarcoma. Heat map of myeloid sarcoma cases based on

444 percent positivity of tumor cells for IRF8, CD34, or MPO by immunohistochemistry.

Figure 2: Representative case of myeloid sarcoma at 2X, 20X magnification. This tumor shows

447 strong IRF8 expression in the monoblastic population of tumor cells and MPO staining in the

448 granulocytic population (Case 8 in Figure 1). IRF8 expression is dimly observed in the mantle

449 zone B cells adjacent to neoplastic cells.

Figure 3: IRF8 and lysozyme staining in monocytic malignancies. Double stain with IRF8

452 (brown) and lysozyme (red) highlights double-positive monoblasts in a case of myeloid sarcoma

453 (Case 1) and lysozyme single-positive monocytes in the skin (Case 2).

Figure 4: Expression patterns of BPDCN in three representative patients. Case 1 shows a mid-

456 chest skin biopsy. Case 2 shows a bone marrow biopsy. Case 3 shows a left chest skin biopsy. All

457 images taken at 200x magnification.

Figure 5: Representative cases of IRF8 immunohistochemistry from pan-cancer TMA. Case 1

460 shows a squamous cell skin carcinoma with IRF8 staining of infiltrating lymphocytes but not

461 neoplastic cells. Case 2 shows a gastric adenocarcinoma with a similar staining pattern to Case

462 1. Case 3 shows a testicular lymphoma with IRF8 staining of large, polymorphic tumor cells.

463 Case 4 shows a representative case of an IR8-positive TNBC. 
465 Figure 6: IRF8 expression in cancerous tissues (red) and normal tissues (gray). Box plots

466 marked with a red asterisk indicate a statistically significant difference $(p<.05)$ between tumor

467 and normal tissue. BLCA - Bladder Urothelial Carcinoma, BRCA - Breast Invasive Carcinoma,

468 COAD - Colon Adenocarcinoma, DLBC - Lymphoid Neoplasm Diffuse Large B-Cell Lymphoma,

469 KIRP - Kidney Renal Papillary Cell Carcinoma, LAML - Acute Myeloid Leukemia, LIHC - Liver

470 Hepatocellular Carcinoma, LUAD - Lung Adenocarcinoma, LUSC - Lung Squamous Cell

471 Carcinoma, OV - Ovarian Serous Cystadenocarcinoma, SARC - Sarcoma,

472 STAD - Stomach Adenocarcinoma, TGCT - Testicular Germ Cell Tumors.

474 Table 1: IRF8 expression in normal tissues and malignancies of different origins included in a

475 pan-cancer TMA.

\begin{tabular}{llllr}
\hline Tissue & Subtype & Negative & Positive & Total \\
\hline Bladder & Normal Bladder & $3(100 \%)$ & 0 & 3 \\
& Papillary Transitional Cell Carcinoma & $1(100 \%)$ & 0 & 1 \\
& Papillary Urothelial Carcinoma & $4(100 \%)$ & 0 & 4 \\
& Serous Adenocarcinoma & $1(100 \%)$ & 0 & 1 \\
& Urothelial Carcinoma & $10(100 \%)$ & 0 & 10 \\
Breast & Ductal Carcinoma & $9(100 \%)$ & 0 & 9 \\
& Lobular Carcinoma & $1(100 \%)$ & 0 & 1 \\
\multirow{5}{*}{ Kolon } & Normal Colon & $2(100 \%)$ & 0 & 2 \\
& Adenocarcinoma & $13(100 \%)$ & 0 & 13 \\
& Normal Kidney & $3(100 \%)$ & 0 & 3 \\
& Papillary Renal Cell Carcinoma & $10(100 \%)$ & 0 & 10 \\
& Renal Cell Carcinoma & $4(100 \%)$ & 0 & 4 \\
& Normal Liver & $4(100 \%)$ & 0 & 4 \\
& Hepatocellular Carcinoma & $14(100 \%)$ & 0 & 14 \\
\multirow{5}{*}{ Lung } & Mixed Hepatocholangiocarcinoma & $1(100 \%)$ & 0 & 1 \\
& Normal Lung & $2(100 \%)$ & 0 & 2 \\
& Adenocarcinoma & $7(100 \%)$ & 0 & 7
\end{tabular}




\begin{tabular}{llllr} 
& Neuroendocrine Carcinoma & $1(100 \%)$ & 0 & 1 \\
\multirow{5}{*}{ Ovary } & Squamous Cell Carcinoma & $8(100 \%)$ & 0 & 8 \\
& Normal Ovary & $4(100 \%)$ & 0 & 4 \\
& Adenocarcinoma & $12(100 \%)$ & 0 & 12 \\
& Normal Pancreas & $3(100 \%)$ & 0 & 3 \\
& Adenocarcinoma & $1(100 \%)$ & 0 & 1 \\
\multirow{5}{*}{ Skin } & Endocrine Carcinoma & $12(100 \%)$ & 0 & 12 \\
& Neuroendocrine Carcinoma & $2(100 \%)$ & 0 & 2 \\
& Normal Skin & $2(100 \%)$ & 0 & 2 \\
Testis & Squamous Cell Carcinoma & $14(100 \%)$ & 0 & 14 \\
& Normal Stomach & $2(100 \%)$ & 0 & 2 \\
& Adenocarcinoma & $10(100 \%)$ & 0 & 2 \\
& Normal Testis & $2(100 \%)$ & 0 & 1 \\
& Embryonal Carcinoma & $1(100 \%)$ & 0 & 2 \\
& Leydig Cell Carcinoma & $2(100 \%)$ & 0 & 1 \\
& Lymphoma & 0 & $1(100 \%)$ & 6 \\
& Mixed Germ Cell Carcinoma & $6(100 \%)$ & 0 & 5 \\
\hline
\end{tabular}

477 Table 2: IRF8 expression in different types of sarcoma included in sarcoma-specific TMAs.

\begin{tabular}{lllr}
\hline Sarcoma Type & Negative & Positive & Total \\
\hline Desmoplastic small round cell tumor & $30(100 \%)$ & 0 & 30 \\
Ewing sarcoma & $24(100 \%)$ & 0 & 24 \\
Synovial sarcoma & $45(100 \%)$ & 0 & 45 \\
Undifferentiated pleomorphic sarcoma & $12(100 \%)$ & 0 & 12 \\
\hline
\end{tabular}


IRF8 CD34 MPO

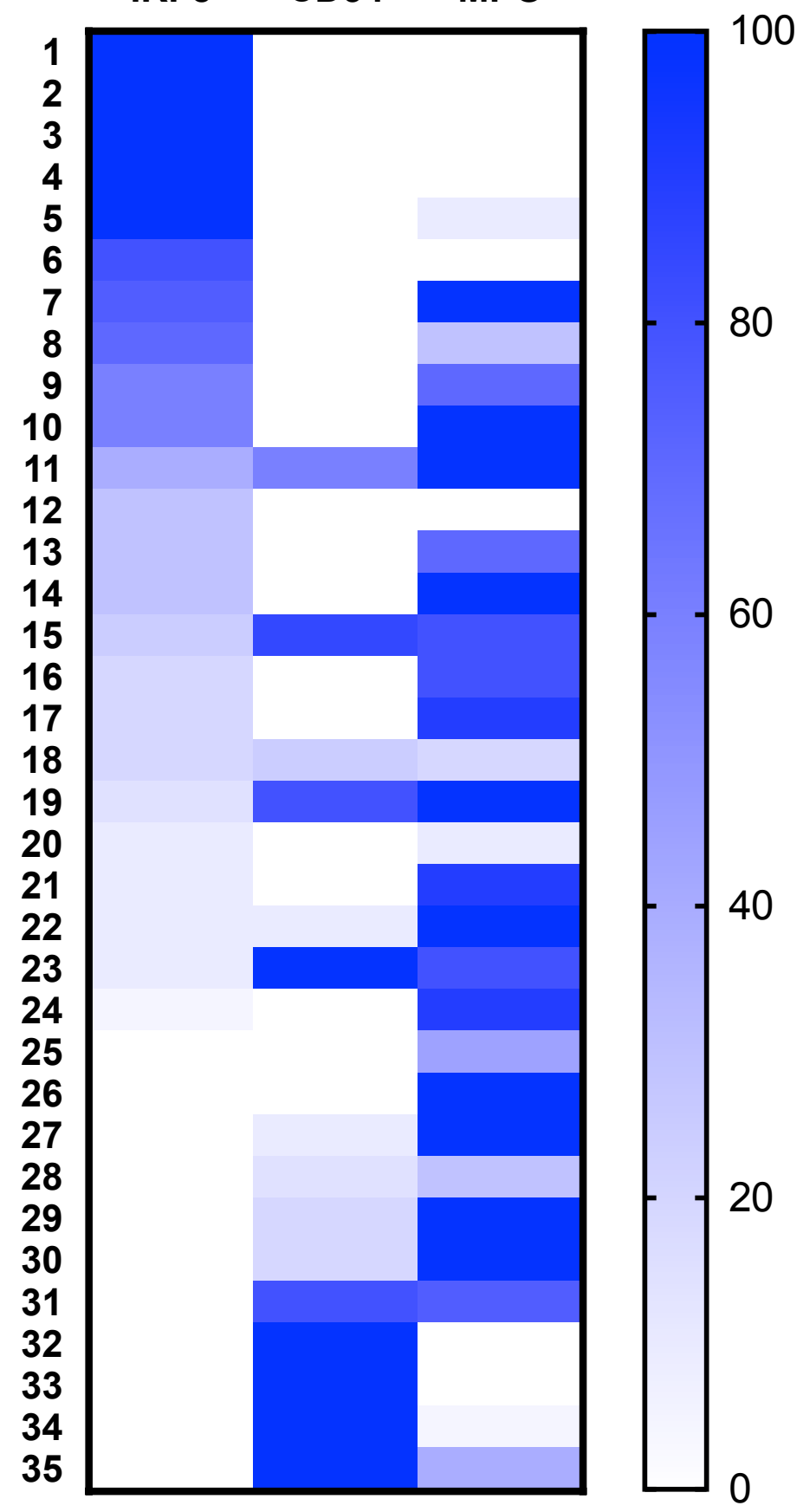


2X

$H \& E$

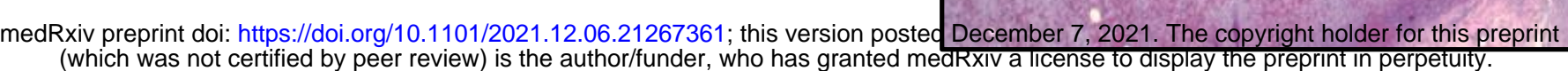
MPO
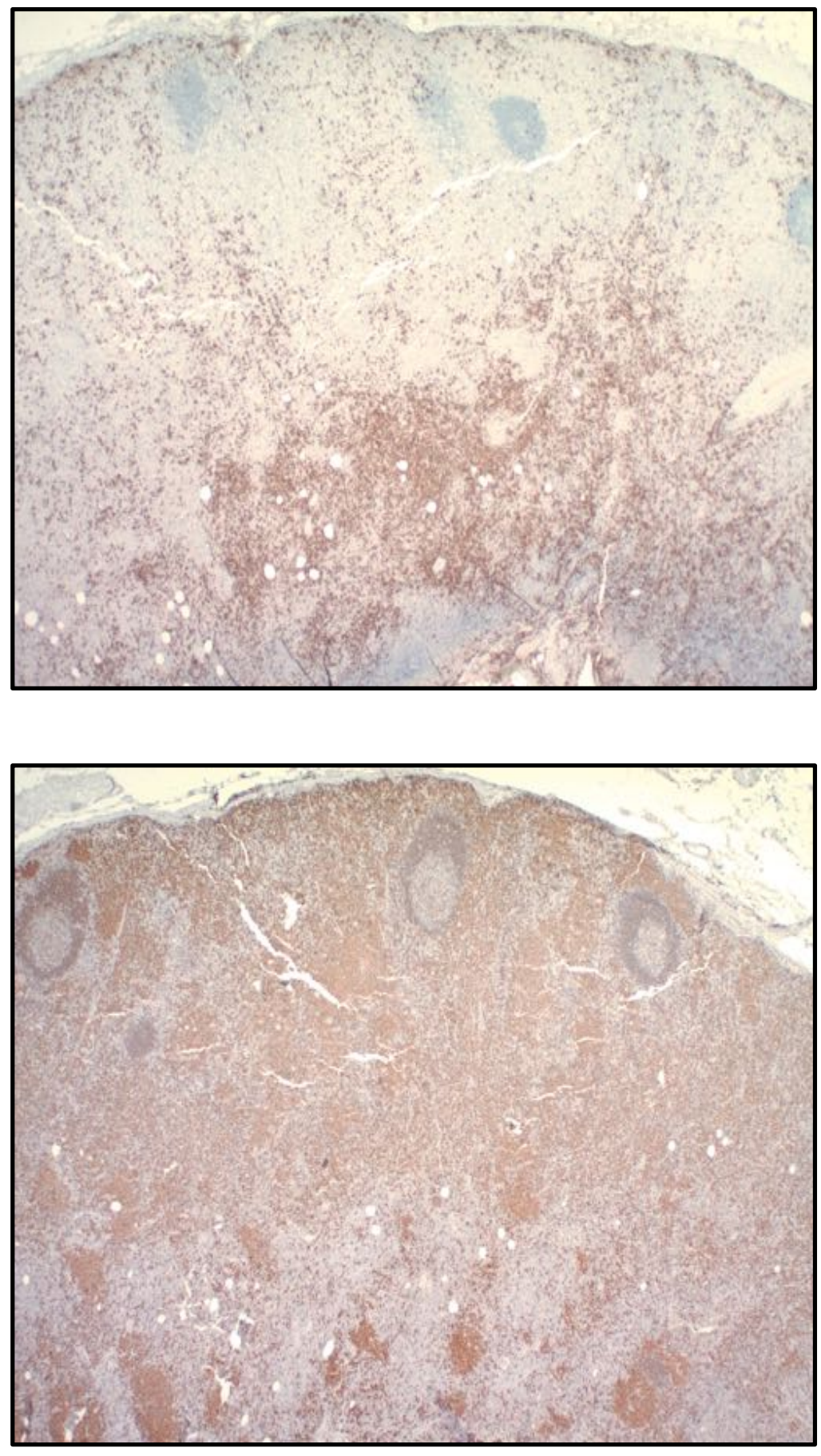

20X
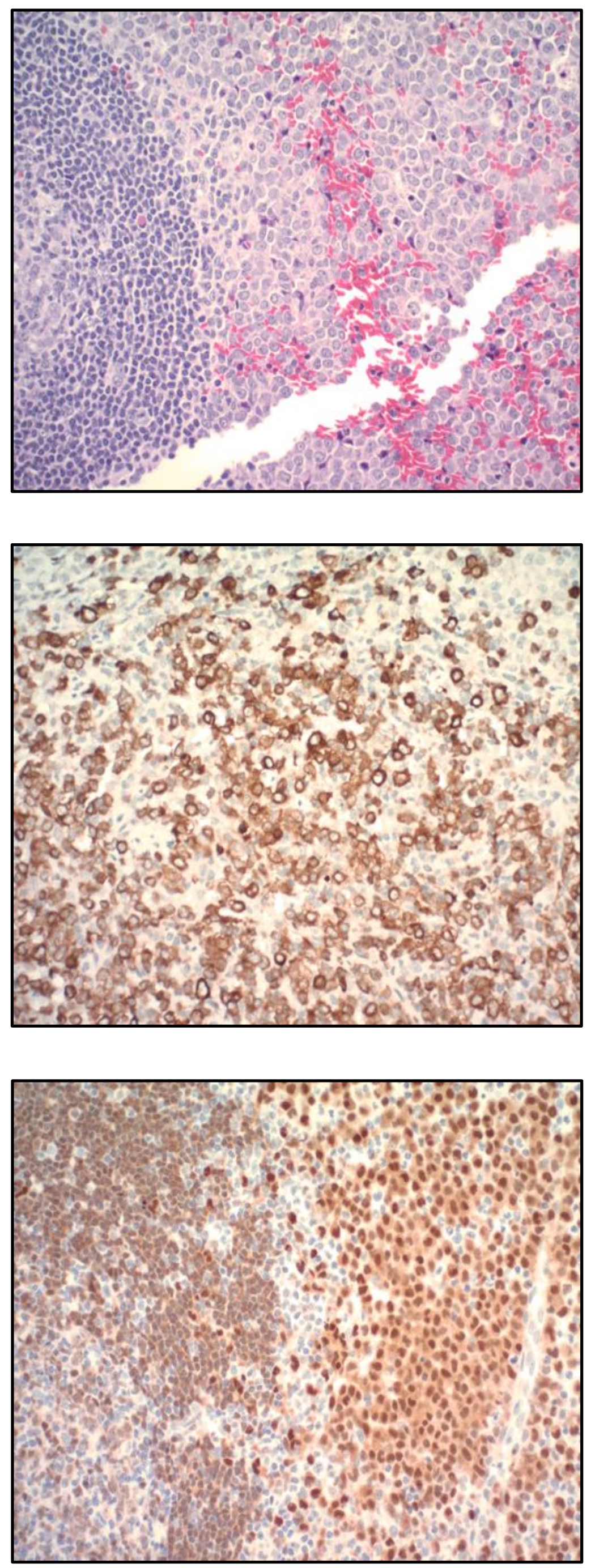


\section{CASE 1}

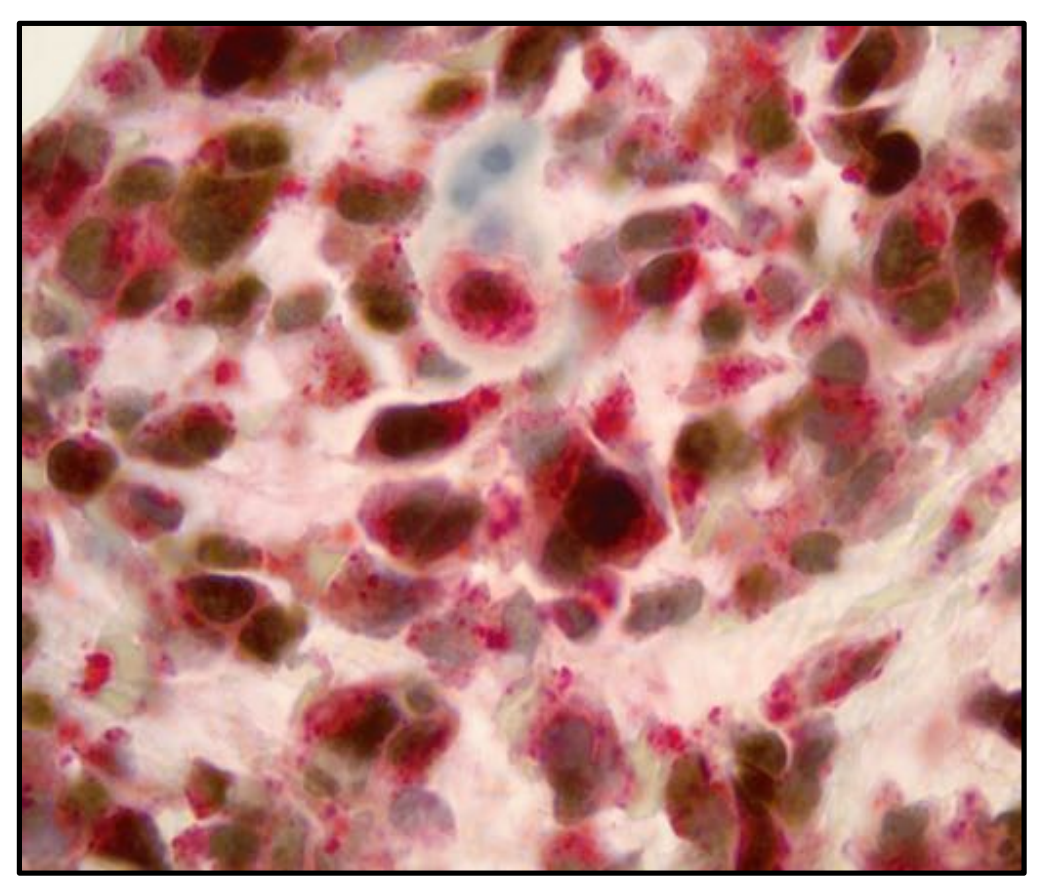

CASE 2

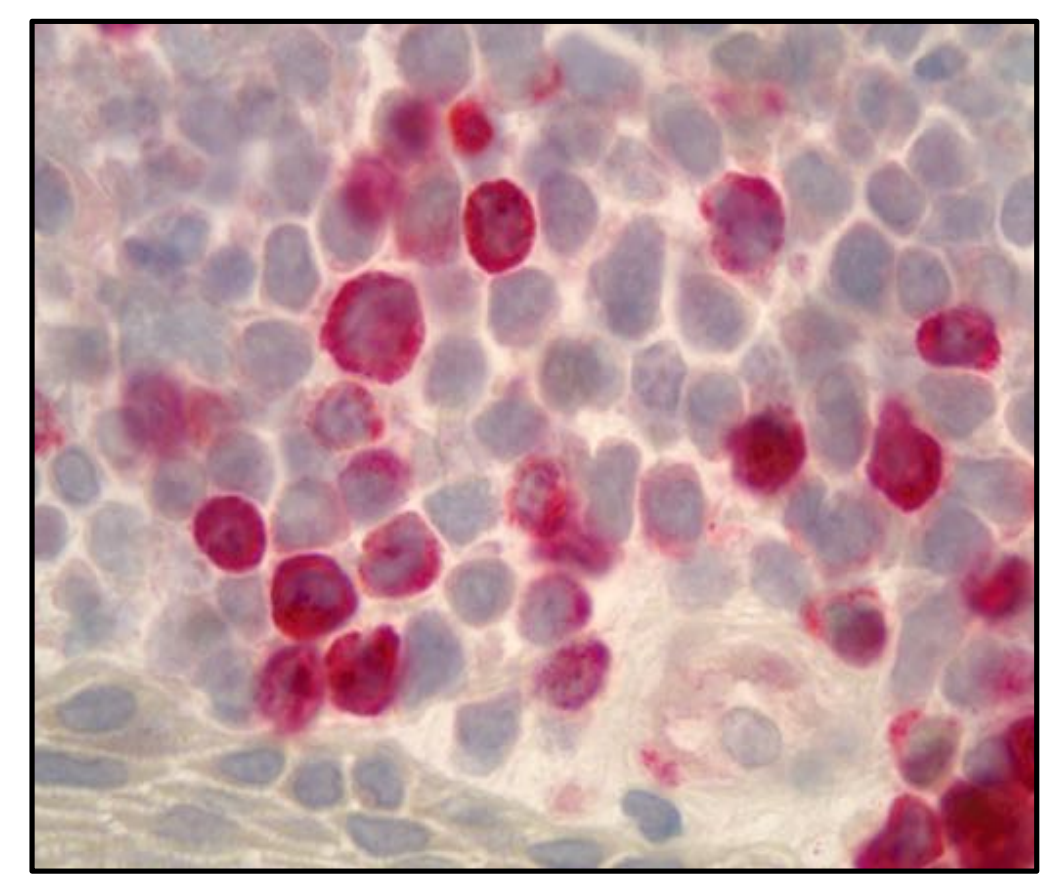


H\&E

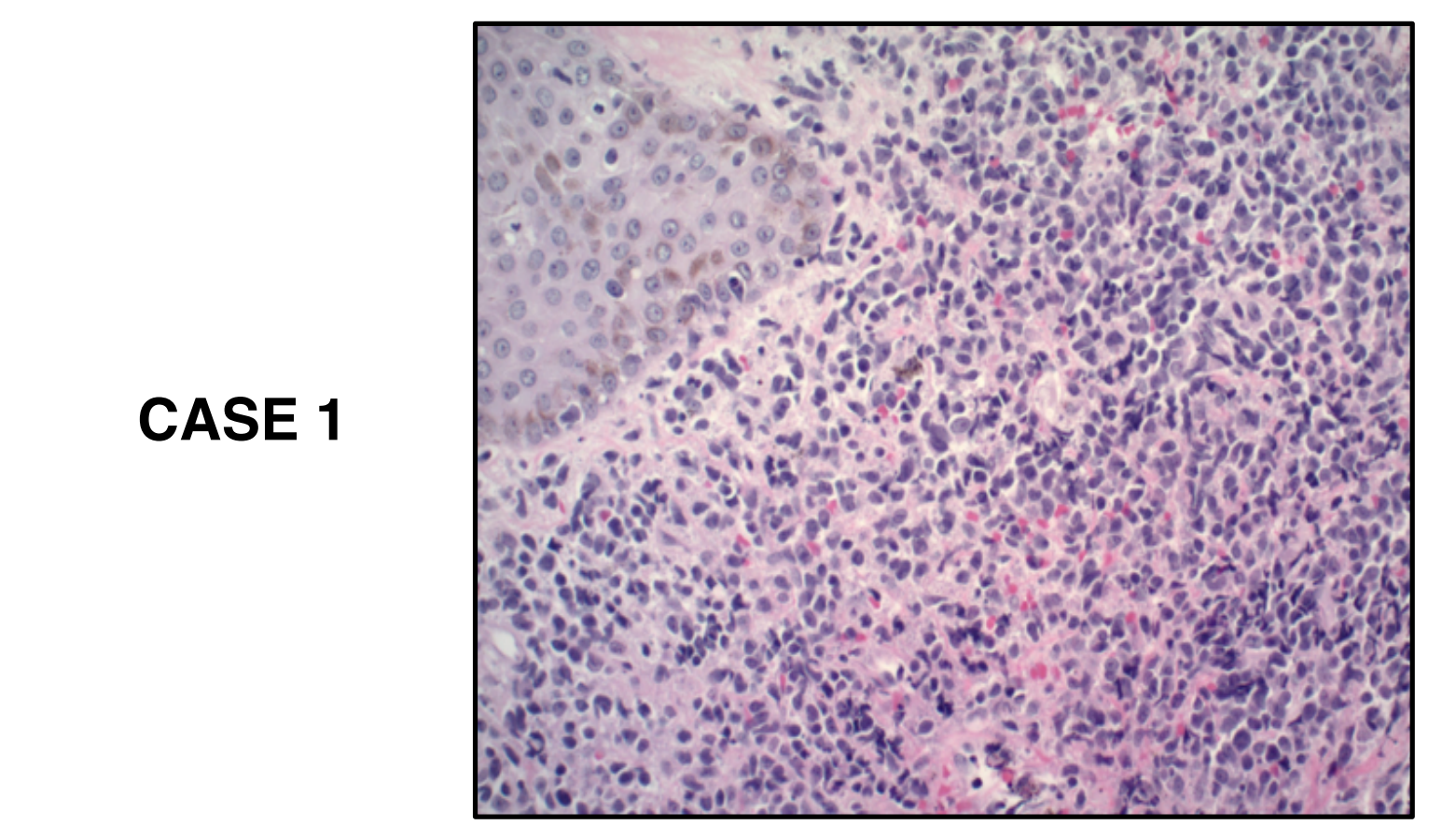

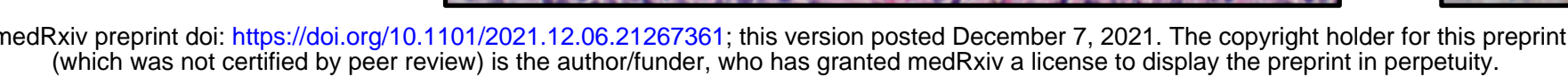

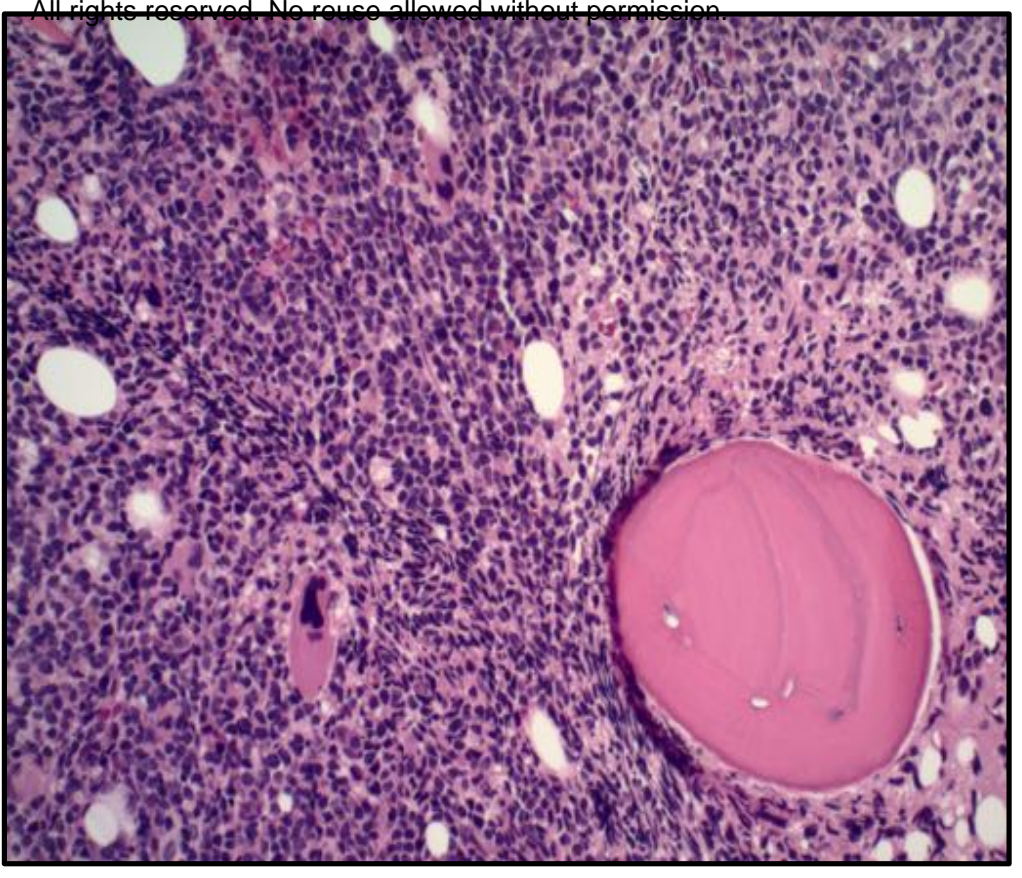

CASE 2

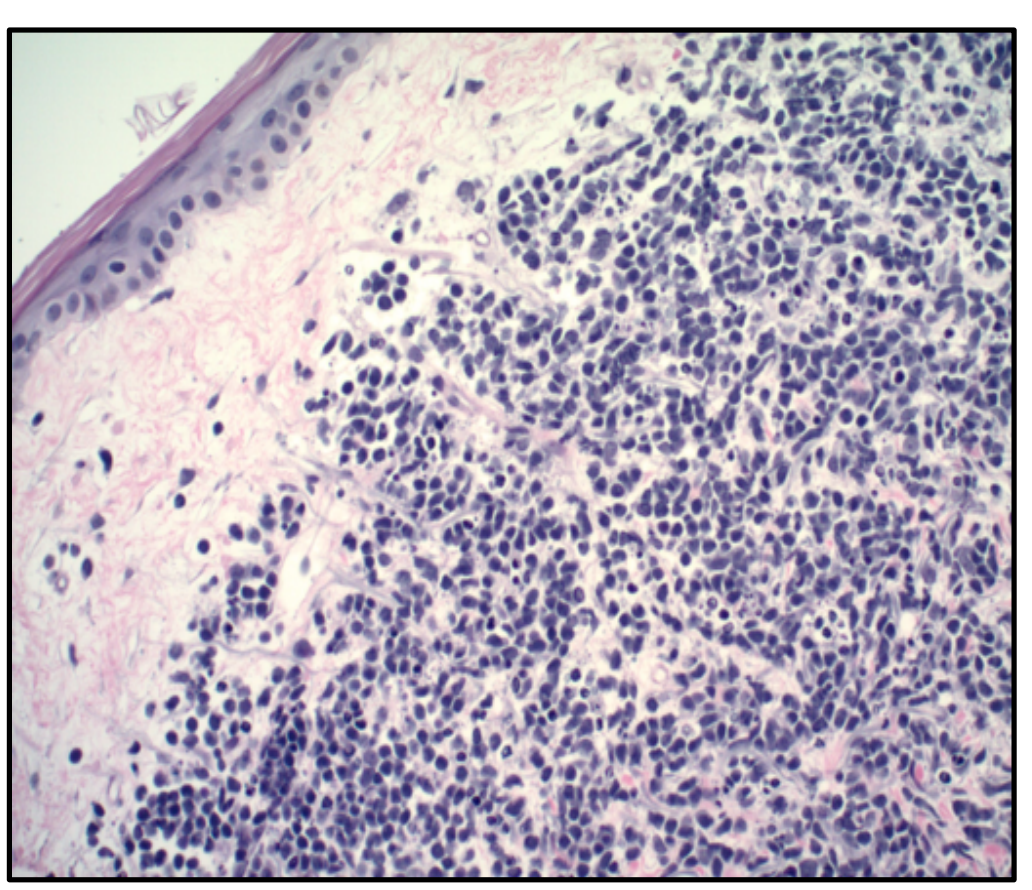

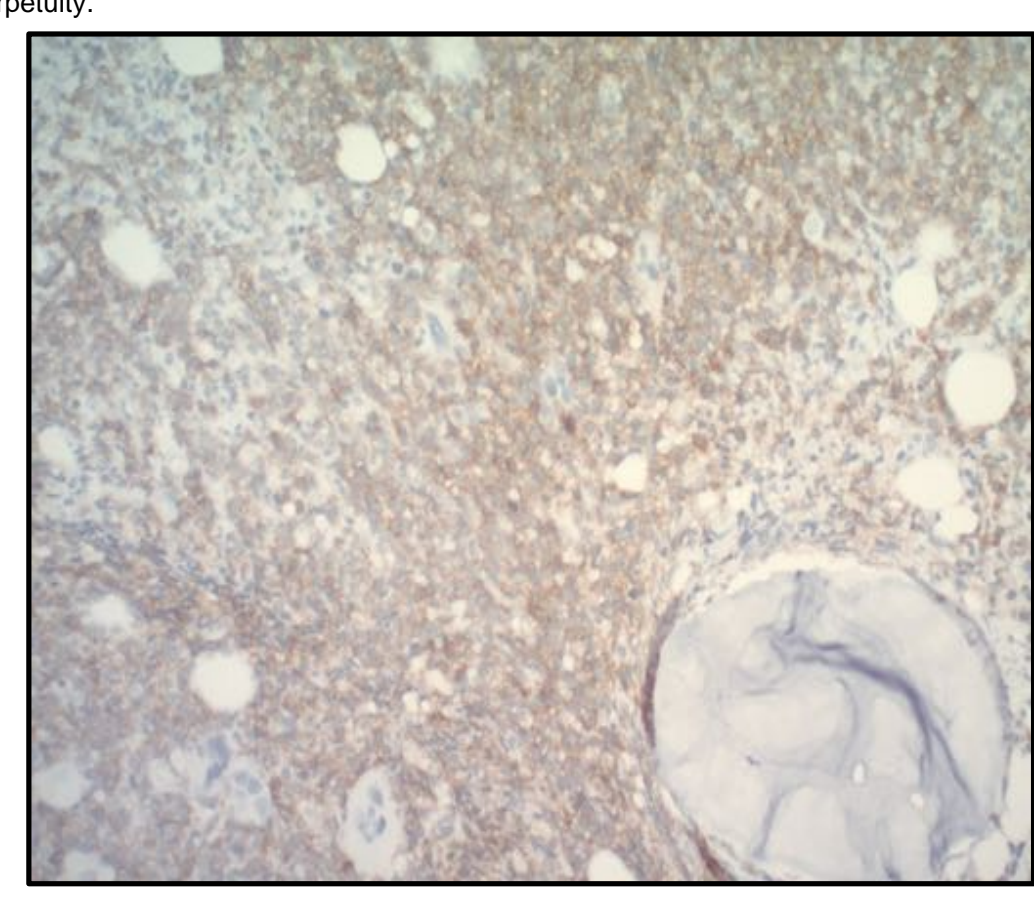

CD123
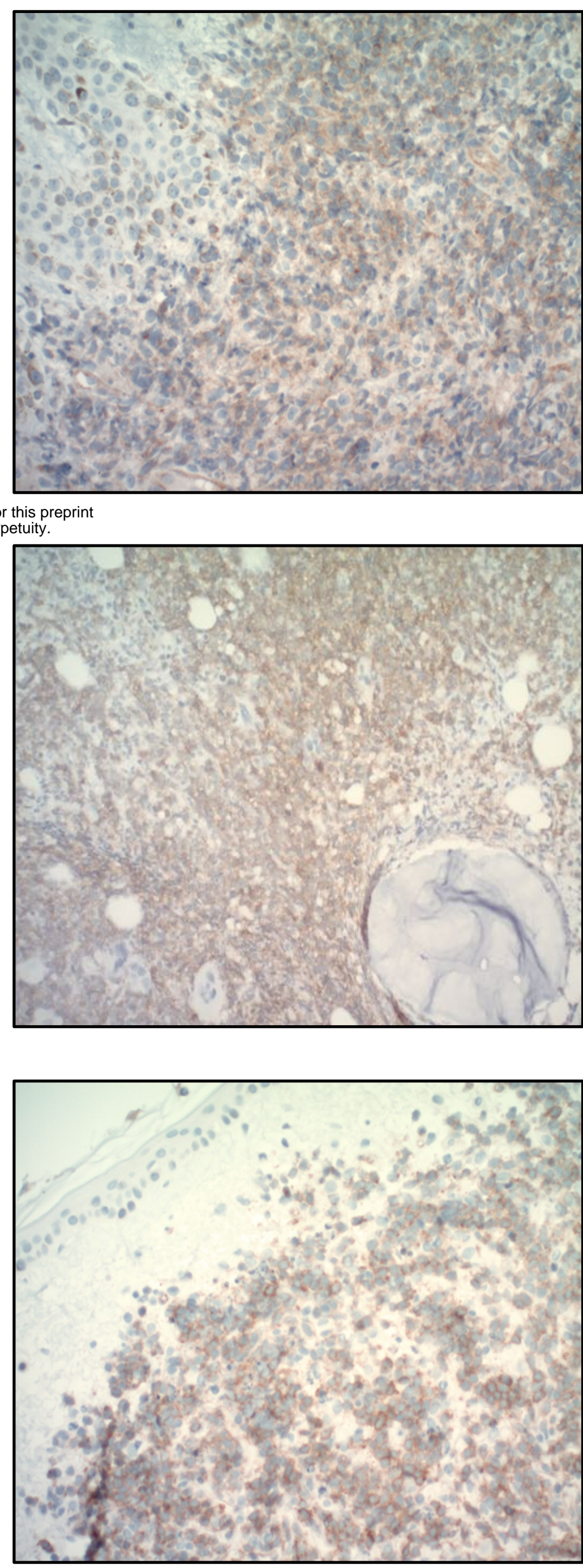

IRF8
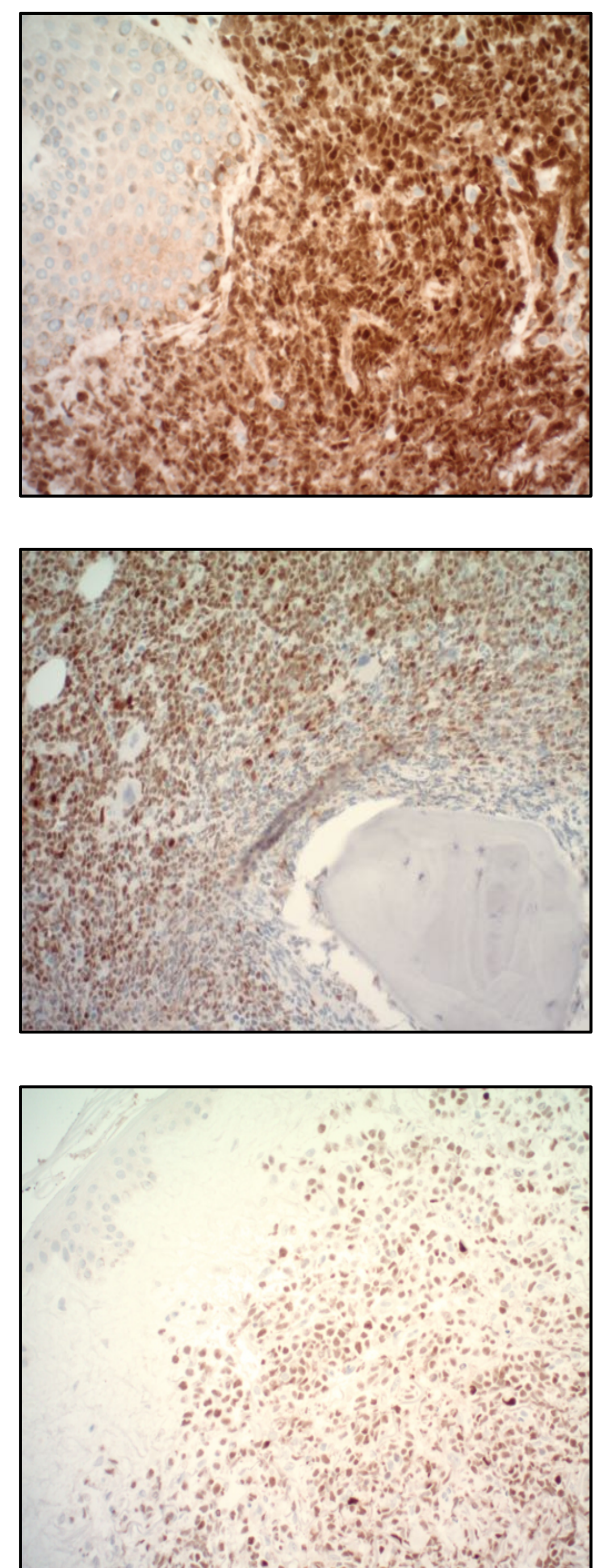
H\&E

CASE 1

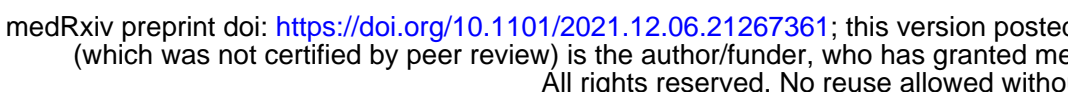
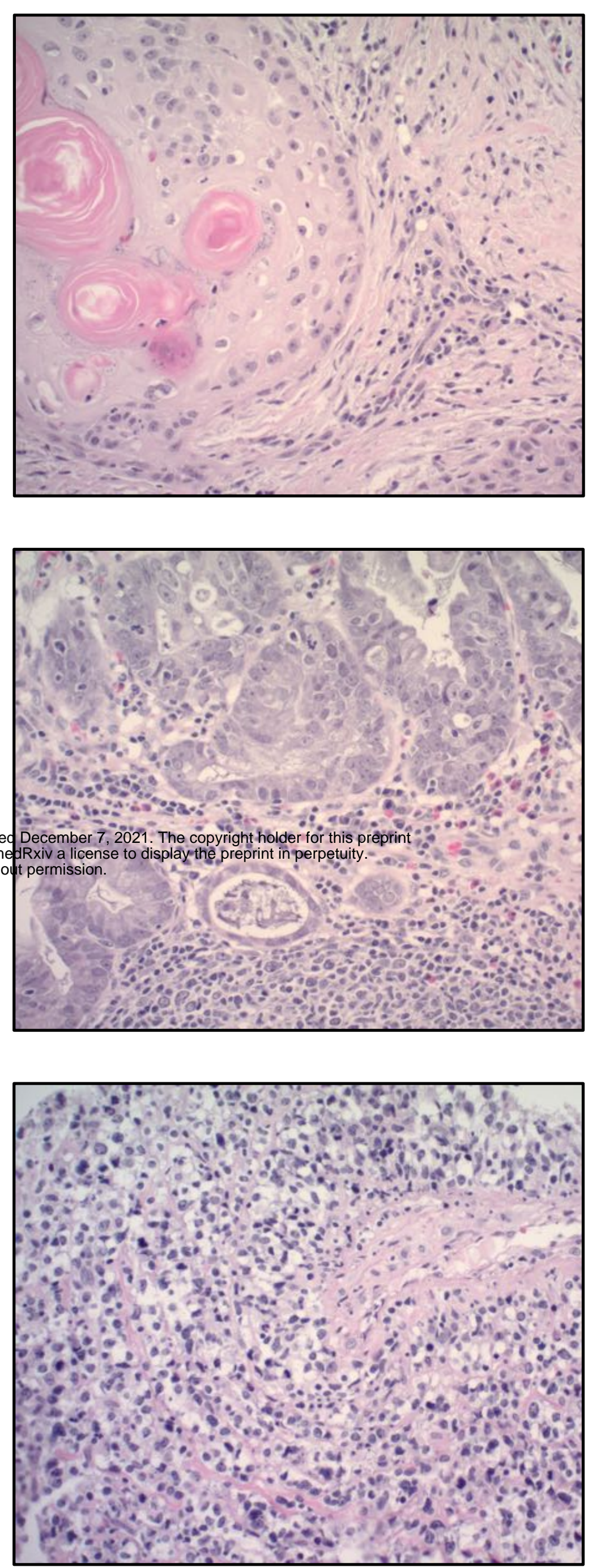

CASE 3

CASE 4

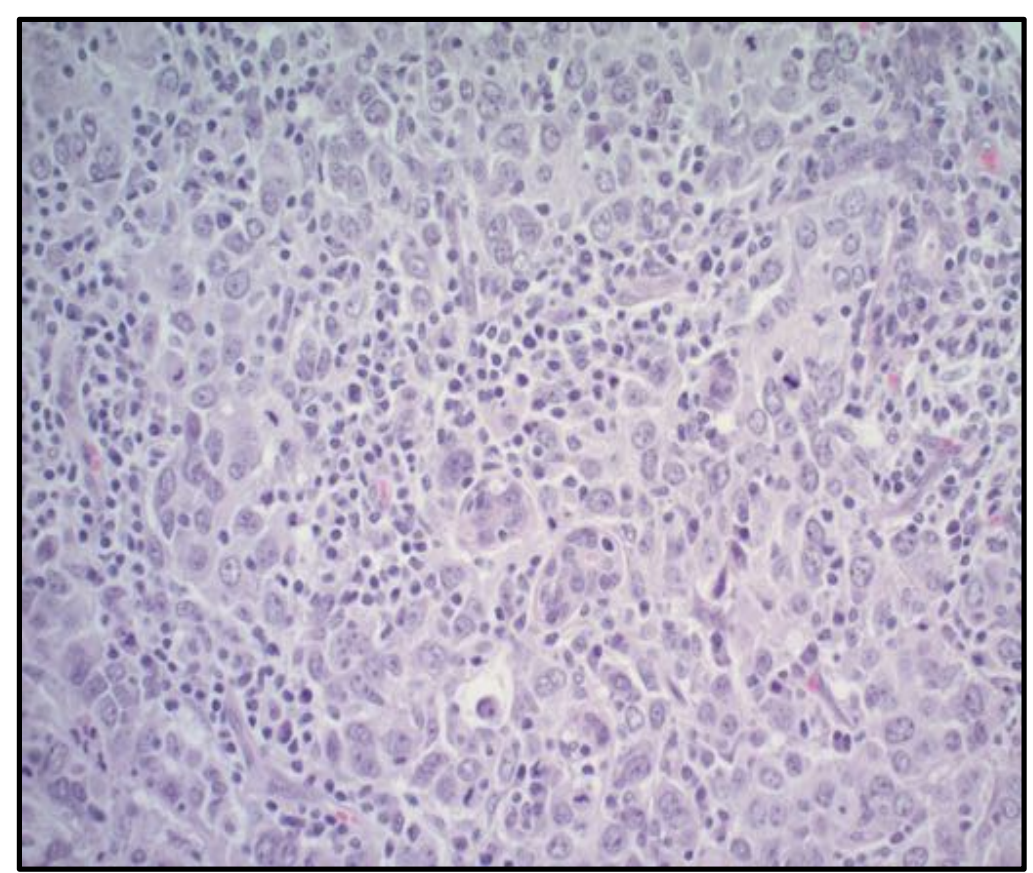

IRF8
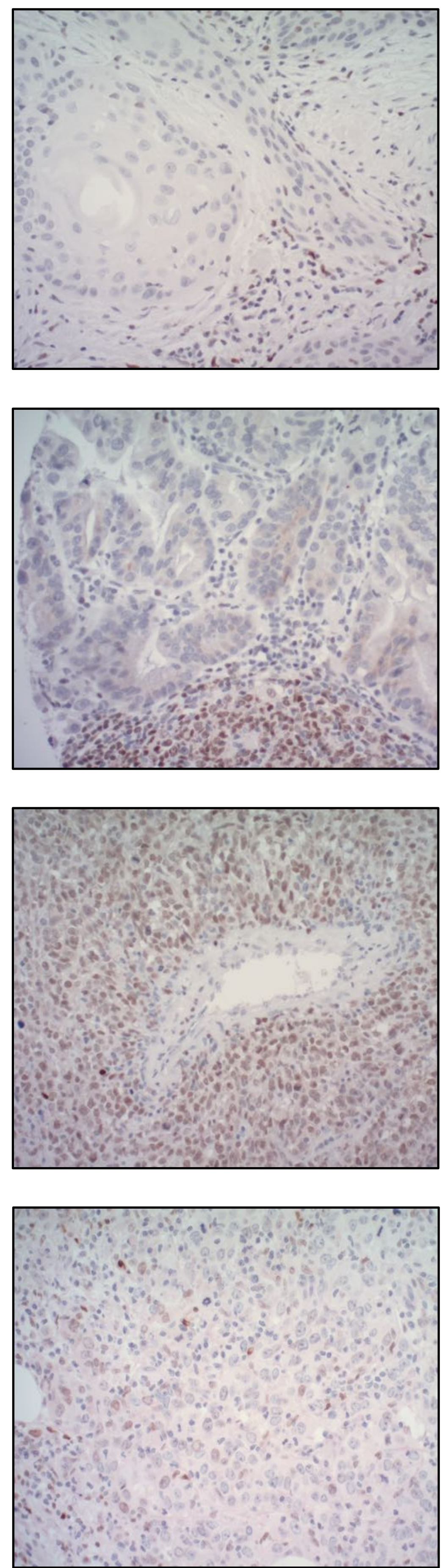


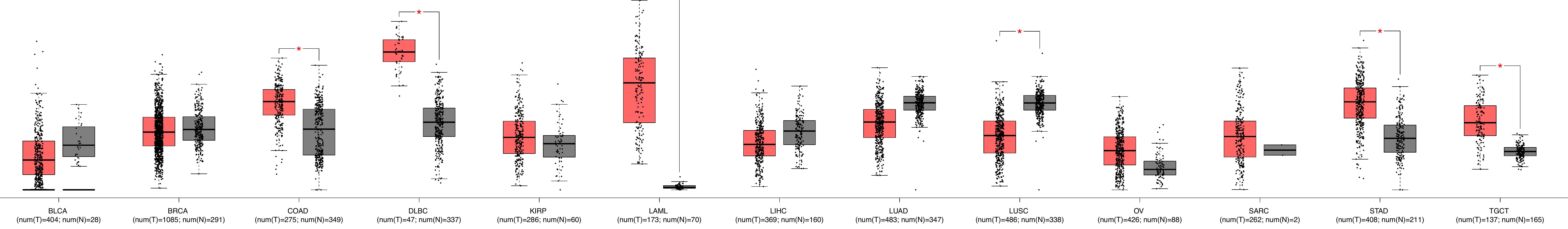

